\title{
KESULITAN BELAJAR SISWA PADA MATA PELAJARAN BAHASA INDONESIA DI SEKOLAH DASAR
}

\author{
Ahmad Khawani, Andi Prastowo \\ Uin Sunan Kalijaga Yogyakarta, Uin Sunan Kalijaga Yogyakarta \\ e-mail: 21204081031@student.uin-suka.ac.id, andi.prastowo@uin-suka.ac.id
}

\begin{abstract}
The purpose of this study is to explore students' learning difficulties in the Indonesian class II of SDN 6 Darul Hikmah, Aceh Jaya Regency in the 2020/2021 school year, and to explore the factors that cause learning difficulties Indonesian in class II SDN 6 Darul Hikmah, Aceh Jaya Regency in the 2020/2021 school year. This study uses a kualitattive research design with case studies. The subjects in this study were students of grade II SDN 6 Darul Hikmah, Aceh Jaya Regency in the 2020/2021 school year. The data collection techniques used in this study are Observation and Interview. Analysis techniques using miles and huberman models are reduction, display, and verification. The result of this study is that there are internal and external factors of students in learning Indonesian, especially in students' reading learning materials. The internal factor is the lack of motivation and interest in reading from the student itself, students are still not motivated in following the indonesian language learning process and students' interest in learning Indonesian is still lacking. The external factors are first: the lack of creativity of the teacher in the learning process takes place, so that it makes students saturated and less pleasant in following the learning process Indonesian, then the methods used by teachers are also not varied and less attractive to students. Second: parents' lack of attention and encouragement towards a child's learning achievement, especially in the process of learning to read. Based on the results of observations and interviews conducted in class II SDN 6 Darul Hikmah, Aceh Jaya Regency, it can be concluded that there are 5 students out of 13 students who are still having difficulties in the process of learning to read.
\end{abstract}

Keywords: Learning Difficulty, Reading Difficulty, Elementary School

\begin{abstract}
ABSTRAK
Tujuan penelitian ini adalah untuk mendeksripsikan kesulitan belajar siswa pada pelajaran Bahasa Indonesia kelas II SDN 6 Darul Hikmah, Kabupaten Aceh Jaya tahun ajaran 2020/2021, dan untuk mendeksripsikan faktor-faktor yang menyebabkan kesulitan belajar Bahasa Indonesia di kelas II SDN 6 Darul Hikmah, Kabupaten Aceh Jaya tahun ajaran 2020/2021. Penelitian ini menggunakan rancangan penelitian Kualitattif dengan studi kasus. Subjek dalam penelitian ini adalah siswa kelas II SDN 6 Darul Hikmah, Kabupaten Aceh Jaya tahun ajaran 2020/2021. Teknik pengumpulan data yang digunakan dalam penelitian ini adalah Observasi dan Wawancara. Teknik analisis data menggunakan model Miles dan Huberman yaitu reduksi data, display data, dan verifikasi. Hasil dari penelitian ini adalah terdapat faktor internal dan eksternal siswa dalam belajar Bahasa Indonesia, khususnya pada materi belajar membaca siswa.
\end{abstract}


Adapun faktor internalnya ialah kurangnya motivasi dan minat membaca dari diri siswa itu sendiri, siswa masih belum termotivasi dalam mengikuti proses pembelajaran bahasa indonesia dan minat siswa dalam mempelajari Bahasa Indonesia masih kurang. Adapun faktor eksternalnya ialah pertama: kurangnya kreativitas guru wali kelasnya dalam proses pembelajaran berlangsung, sehingga membuat siswa jenuh dan kurang menyenangkan dalam mengikuti proses pembelajaran Bahasa Indonesia, kemudian metode yang digunakan guru juga tidak bervariasi dan kurang menarik bagi siswa. Kedua: kurangnya perhatian dan dorongan orang tua terhadap prestasi belajar seorang anak, terutama pada proses belajar membaca. Berdasarkan hasil observasi dan wawancara yang dilakukan dikelas II SDN 6 Darul Hikmah, Kabupaten Aceh Jaya, maka dapat disimpulkan bahwa terdapat 5 siswa dari 13 siswa yang masih mengalami kesulitan dalam proses belajar membaca.

Kata Kunci : Kesulitan Belajar, Kesulitan Membaca, Sekolah Dasar

\section{PENDAHULUAN}

Untuk mencapai tujuan akhir yang maksimal, maka menuntut semua elemen pendidikan mulai dari tenaga kependidikan, orang tua, peserta didik, masyarakat maupun pemerintah agar senantiasa selalu mendukung hal-hal yang dapat menunjang keberhasilan pendidikan. Berbagai usaha telah dilakukan untuk meningkatkan mutu pendidikan nasional, antara lain melalui berbagai pelatihan, peningkatan kualifikasi guru, penyempurnaan kurikulum, pengadaan buku dan alat pelajaran, perbaikan sarana dan prasarana lainnya, serta peningkatan manajemen sekolah. Namun belum menunjukkan peningkatan yang memadai. ${ }^{1}$

Kegiatan pembelajaran di sekolah bertujuan untuk membawa siswa menuju ke arah yang lebih baik. Dalam proses pembelajaran diperlukan adanya motivator dan fasilitator yang baik yaitu dengan hadirnya seorang guru di depan kelas. Menurut Makmun "guru merupakan salah satu komponen dalam proses belajar mengajar. Proses belajar mengajar merupakan proses interaksi yang terjadi antara guru dengan siswa dengan tujuan mencapai hasil pembelajaran yang maksimal atau memenuhi KKM. ${ }^{2}$

Ada empat kompetensi dasar yang harus dimiliki siswa pada pembelajaran bahasa Indonesia tingkat sekolah dasar yakni: aspek berbicara, menyimak, membaca dan menulis. Dalam kurikulum 2013 semua aspek tersebut terintegrasi ke dalam KI (Kompetensi Inti) dan KD (Kompetensi Dasar) pada masing-masing sub tema yang telah ditentukan.

\footnotetext{
${ }^{1}$ Mardhatillah, "Pengembangan Media Pembelajaran Interaktif Berbasis TIK pada Materi Teks Narasi di SDN 106161 Laut Dendang," Jurnal Tematik 1, no. 16 (2015), hlm. 78.

${ }^{2}$ Makmun, Psikologi Pendidikan (Bandung: Remaja Rosdakarya, 2001), hlm. 7.
} 
Penelitian yang dilakukan oleh I Gst. Ayu Winiari, dkk. Hasil penelitian menunjukkan bahwa siswa mengalami kesulitan dalam menguasai keterampilan menulis dan membaca, adapun keterampilan yang paling tinggi tingkat kesulitannya yaitu keterampilan membaca. $^{3}$

Penelitian yang dilakukan oleh Ina Magdalena, dkk. Hasil penelitian menunjukkan bahwa kesulitan siswa dalam memahami materi Bahasa Indonesia dipicu oleh beberapa hal terutama pada kemampuan guru yang kurang optimal dalam menyajikan pembelajaran dengan kurang menguasai bahan belajar, tidak menggunakan metode dan media yang tepat, dan kurang mampu mengelola kelas dan tidak tersedianya buku pegangan atau buku paket bagi siswa. ${ }^{4}$

Penelitian yang dilakukan oleh Nani, dkk. Hasil Penelitian menunjukkan bahwa siswa mengalami kesulitan belajar pada pembelajaran Bahasa Indonesia yakni meliputi: kesulitan siswa dalam menyimak, kesulitan berbicara, kesulitan membaca, dan kesulitan dalam menulis. ${ }^{5}$

Penelitian yang dilakukan oleh Safni Febri Anzar, dkk. Hasil penelitian menunjukkan bahwa kesulitan siswa dalam memahami materi Bahasa Indonesia dipicu oleh beberapa hal terutama pada kemampuan guru yang kurang optimal dalam menyajikan pembelajaran dengan kurang menguasai bahan belajar, tidak menggunakan metode dan media yang tepat, dan kurang mampu mengelola kelas dan tidak tersedianya buku pegangan atau buku paket bagi siswa. ${ }^{6}$

Berdasarkan penelitian-penelitian diatas maka dapat disimpulkan bahwa kompetensi guru dalam pelaksanaan pembelajaran itu sangatlah penting. ${ }^{7}$ Kompetensi guru mempunyai posisi yang penting dalam menentukan kualitas pendidikan disuatu tempat atau lembaga pendidikan. Apalagi dalam hal ini Bahasa Indonesia memiliki peran sentral dalam perkembangan intelektual, sosial dan Emosional peserta didik, serta merupakan penunjang keberhasilan dalam mempelajari semua bidang studi.

\footnotetext{
${ }^{3}$ I Gst. Ayu Winiari dan dkk, "Analisis Kesulitan-Kesulitan Belajar Bahasa Indonesia Kelas V Dalam Implementasi Kurikulum 2013 Di Sd Pilotingse-Kabupaten Gianyar,” Jurnal PGSD Universitas Ganesha Jurusan PGSD 3, no. 1 (2015), hlm.10.

${ }^{4}$ Ina Magdalena dan dkk, "Analisis Kesulitan Belajar Siswa Pada Pembelajaran Bahasa Indonesia Di Kelas 5 Sdn Dukuh 3," Jurnal Pendidikan dan Dakwah 3, no. 2 (2021)hlm. 367.

${ }^{5}$ Nani dan dkk, "Analisis Kesulitan Belajar Siswa Pada Pembelajaran Bahasa Indonesia Di Kelas V SDN 12 Singkawang," Journal of Educational Review and Research 2, no. 1 (2019), hlm. 61.

${ }^{6}$ Safni Febri Anzar dan dkk, "Analisis Kesulitan Belajar Siswa Pada Pembelajaran Bahasa Indonesia Di Kelas V Sd Negeri 20 Meulaboh Kabupaten Aceh Barat Tahun Ajaran 2015/2016, Meulaboh,” Bina Gogik 4, no. 1 (2017), hlm. 63.

${ }^{7}$ Imam Suraji, “Urgensi Kompetensi Guru," Forum Tarbiyah 10, no. 2 (t.t.): hlm. 241.
} 
Melihat dari permasalahan di atas, maka timbul inisiatif dari penulis untuk melakukan penelitian lebih lanjut dengan judul "Kesulitan Belajar Siswa Pada Mata Pelajaran Bahasa Indonesia Di Sekolah Dasar”.

\section{METODE PENELITIAN}

Jenis penelitian yang digunakan dalam penelitian ini adalah penelitian Kualitatif dengan pendekatan studi kasus. Penelitian kualitatif merupakan penelitian yang bertujuan untuk memahami fenomena yang dialami oleh subjek penelitian. Lebih cocok digunakan untuk meneliti hal-hal yang berkaitan dengan penelitian perilaku, sikap, motivasi, persepsi dan tindakan dari subjek. Maka dari itu peneliti memilih penelitian Kualitatif dengan Studi Kasus karena merasa cocok dengan subjek yang ingin diteliti.

Teknik pengambilan sampel dalam penelitian ini menggunakan purposive sampling. Purposive sampling adalah teknik pengambilan sampel dengan pertimbangan tertentu. ${ }^{8}$ Adapun yang menjadi sampel dalam penelitian ini adalah siswa kelas 2 SDN 6 Darul Hikmah yang berjumlah 13 orang siswa yang terdiri dari 3 siswa laki-laki dan 10 siswa perempuan.

Instrument yang digunakan dalam penelitian ini yaitu observasi dan wawancara. Observasi adalah suatu teknik pengumpulan data dengan cara turun langsung ke lapangan atau tempat penelitian. ${ }^{9}$ Dalam penelitian ini observasi dimulai dengan mengidentifikasi tempat yang hendak diteliti, mengamati dan mencatat segala hal yang berkaitan dengan kesulitan-kesulitan belajar siswa. Sedangkan wawancara adalah komunikasi antar dua pihak atau lebih dengan tujuan tertentu, misalnya untuk mengumpulkan informasi atau data. ${ }^{10}$ Wawancara dalam penelitian ini dilakukan untuk mengetahui apa saja kesulitan-kesulitan belajar siswa dalam pembelajaran Bahasa Indonesia.

Teknik analisis data dalam penelitian ini menggunakan model Miles dan Huberman. Model interaktif dalam analisis data menurut Miles dan Huberman adalah reduksi data, display data, dan verifikasi. ${ }^{11}$

8 Nugrahani, Farida. Metode Penelitian Kualitatif. Surakarta, 2014, hlm. 212.

${ }^{9}$ Albi Anggito dan Johan Setiawan, Metodologi Penelitian Kualitatif (Jawa Barat: CV Jejak, 2018), hlm. 112.

${ }^{10}$ Fadhillah, Wawancara (Jakarta Timur: UNJ PRESS, 2021), hlm. 2.

${ }^{11}$ Sugiyono, Metodologi Penelitian Kuantitatif, Kualitatif, dan R\&D (Bandung: Alfabeta, 2013), hlm. 246. 


\section{HASIL PENELITIAN DAN PEMBAHASAN}

\section{Kesulitan Belajar}

Kesulitan belajar merupakan gangguan atau keadaan yang menyebabkan siswa tidak dapat belajar sebagaimana mestinya, kesulitan tersebut disebabkan oleh faktor internal dan eksternal pada anak sehingga menyebabkan kesulitan otak dalam mengikuti proses pembelajaran secara normal dalam hal menerima, memproses, dan menganalisis informasi yang didapatkan selama pembelajaran atau dalam proses pembelajaran. ${ }^{12}$

Secara umum kesulitan yang dihadapi siswa bermacam-macam, adapun kesulitan belajar menurut Djamarah melihat kesulitan belajar dari dua aspek, yaitu dari sudut internal dan eksternal. Menurut faktor-faktor anak didik meliputi gangguan atau kekurangan psiko-fisik anak didik, yakni sebagai berikut ${ }^{13}$ :

1. Faktor internal meliputi:

a. Yang sifatnya kognitif (ranah cipta), antara lain rendahnya kapasitas intelektual/intelegensi seorang anak atau peserta didik.

b. Yang bersifat afektif (ranah rasa), antara lain seperti labilnya emosi dan sikap seorang anak atau peserta didik.

c. Yang bersifat psikomotor (ranah karsa), antara lain seperti terganggunya alat-alat indra penglihatan dan pendengaran (mata dan telinga).

2. Faktor eksternal meliputi:

a. Lingkungan keluarga, misalnya ketidakharmonisan dalam rumah tangga dan kehidupan ekonomi keluarga.

b. Lingkungan perkampungan/masyarakat, misalnya daerah kumuh dan teman sebaya atau sepermainan yang nakal.

c. Lingkungan sekolah, misalnya kondisi sarana prasarana sekolah yang tidak memadai atau berkualitas rendah serta letak sekolah yang dekat dengan pasar sehingga terjadi kebisingan dan mengganggu proses belajar mengajar disekolah.

12 Ety Meuklesi Yeni, "Kesulitan Belajar Matematika Disekolah Dasar," Jurnal JUPENDAS 2, no. 2

${ }^{13}$ Djamarah, Proses Belajar Mengajar (Jakarta: Bumi Aksara, 2006), hlm. 235. 
Adapun faktor-faktor penyebab kesulitan belajar dikemukakan juga oleh Slameto yaitu ${ }^{14}$ :

1. Faktor internal

Faktor internal adalah faktor yang bersumber dari dalam diri individu itu sendiri dalam mencapai tujuan belajar. Faktor internal ini sangat besar pengaruhnya tetapi tidak disadari karena dianggap suatu hal yang biasa, sebenarnya faktor ini dapat dibagi dua bagian yaitu faktor fisiologis dan faktor psikologis.

2. Faktor fisiologis

Faktor fisiologis adalah faktor yang bersumber dari dalam individu yang erat hubungannya dengan masalah kejasmanian terutama tentang fungsi alat-alat panca indera, karena panca indera ini merupakan pintu masuk perangsang dari luar kedalam individu yang diolah oleh individu tersebut untuk diterima atau tidak nya suatu pembelajaran.

\section{Faktor psikologis}

Faktor-faktor psikologis yang mempengaruhi proses belajar siswa antara lain:

a. Kecerdasan (intelegensi)

Kecerdasan dapat didefinisikan melalui dua jalan yaitu secara kuantitatif dan kualitatif. Secara kuantitatif, kecerdasan adalah proses belajar untuk memecahkan masalah yang dapat diukur dengan tes inteligensi, sedangkan secara kualitatif kecerdasan merupakan suatu cara berpikir dalam membentuk konstruk bagaimana menghubungkan dan mengelola informasi dari luar yang disesuaikan dengan dirinya.

b. Bakat

Bakat atau aptitude adalah "the capacity to learn". Bakat adalah kemampuan untuk belajar. Jika bakat dikembangkan dengan baik maka akan membuat siswa berhasil dalam proses belajarnya, begitu juga sebaliknya jika siswa kurang memiliki bakat maka akan membuat dirinya kesulitan dalam proses belajar.

c. Minat

${ }^{14}$ Slameto, Belajar dan Faktor-faktor Yang Mempengaruhinya (Jakarta: PT. Rineka Cipta, 2005), hlm. 57- 
Minat menurut Slameto (2010) adalah kecendrungan yang tetap untuk memperhatikan dan mengenang beberapa kegiatan. ${ }^{15}$ (Djamarah, 2008), Setiap orang memiliki minat yang berbeda walaupun kadang sama. ${ }^{16}$ Minat merupakan keinginan dari dalam diri siswa untuk belajar, siswa yang kurang berminat dalam belajar maka akan mengalami kegagalan.

d. Motivasi

Motivasi atau dorongan ialah sesuatu yang dilakukan oleh seseorang atas apa yang ia senangi. Sedangkan motif dapat dikatakan suatu driving force yang artinya sesuatu yang dapat menggerakkan manusia untuk melakukan tindakan atau perilaku dengan tujuan tertentu.

e. Cara belajar.

Cara belajar adalah gaya seseorang yang digunakan untuk memperoleh ilmu pengetahuan.

4. Faktor eksternal

Faktor eksternal adalah faktor yang berasal dari luar diri siswa yang dapat mempengaruhi prestasi siswa. Faktor eksternal yang dapat mempegaruhi prestasi seseorang ada tiga yaitu faktor keluarga, faktor sekolah, dan faktor masyarakat.
a. Faktor Keluarga
b. Faktor Sekolah
c. Faktor Masyarakat

Adapun kesulitan belajar yang dimaksudkan disini ialah kesulitan siswa dalam belajar membaca, sesuai dengan hasil penelitian di SDN 6 Darul Hikmah terdapat beberapa kendala atau kesulitan siswa dalam belajar membaca, adapun kesulitan-kesulitan tersebut disebabkan oleh faktor internal dan eksternal.

5. Faktor Internal

Dari hasil Observasi dan Wawancara yang dilakukan di SDN 6 Darul Hikmah maka dapat disimpulkan bahwa salah satu faktor internal yang menyebabkan siswa mengalami kesulitan dalam proses belajar membaca ialah kurangnya motivasi dan minat membaca dari diri siswa itu sendiri, siswa masih belum termotivasi dalam mengikuti proses pembelajaran bahasa indonesia dan

${ }^{15}$ Slameto. Belajar dan Faktor-faktor Yang Mempengaruhinya. Jakarta: PT. Rineka Cipta, 2005, hlm. 57.

${ }^{16}$ Djamarah. Proses Belajar Mengajar. Jakarta: Bumi Aksara, 2006, hlm. 191. 
minat siswa dalam mempelajari bahasa indonesia masih kurang. Berdasarkan hasil dari Observasi dan Wawancara penulis maka dapat disimpulkan bahwa siswa masih kesulitan dalam proses belajar membaca.

6. Faktor Eksternal

Dari hasil Observasi dan Wawancara yang dilakukan di SDN 6 Darul Hikmah maka dapat disimpulkan ada beberapa faktor eksternal yang menyebabkan siswa mengalami kesulitan dalam proses belajar membaca, adapun faktor-faktor tersebut ialah, pertama: kurangnya kreativitas guru wali kelasnya dalam proses pembelajaran berlangsung, sehingga membuat siswa jenuh dan kurang senang mengikuti proses pembelajaran Bahasa Indonesia, kemudian metode yang digunakan guru juga tidak bervariasi dan kurang menarik bagi siswa. Kedua: kurangnya perhatian dan dorongan orang tua terhadap prestasi belajar seorang anak, terutama pada proses belajar membaca.

Berdasarkan hasil penelitian yang dilakukan di SDN 6 Darul Hikmah maka dapat disimpulkan bahwa terdapat 5 orang siswa dari 13 orang siswa dikelas 2 SDN 6 Darul hikmah masih mengalami kesulitan membaca, kesulitan tersebut disebabkan oleh faktor internal sekolah itu sendiri dan juga faktor eksternal dari diri siswa itu sendiri. Dari hasil penelitian diatas maka dapat kita katakan bahwa penelitian ini memperkaya dari penelitian-penelitian sebelumnya yang sudah pernah dituliskan oleh penulis-penulis sebelumnya. Namun perbedaan nya ialah terdapat lebih sedikit siswa yang mengalami kesulitan membaca daripada siswa yang tidak mengalami kesulitan membaca, dalam kata lain lebih dominan siswa yang sudah mampu membaca daripada siswa yang belum mampu membaca. Dimana pada penelitian terdahulu lebih dominan siswa yang belum mampu membaca dan bisa dikatakan keseluruhan siswa belum mampu membaca.

\section{SIMPULAN}

Berdasarkan hasil observasi dan wawancara yang dilakukan dikelas II SDN 6 Darul Hikmah, Kabupaten Aceh Jaya, maka dapat disimpulkan bahwa terdapat faktor internal dan eksternal kesulitan-kesulitan belajar, faktor internalnya ialah kurangnya motivasi dan minat membaca dari diri siswa itu sendiri, siswa masih belum termotivasi dalam mengikuti proses pembelajaran bahasa indonesia dan minat siswa dalam 
mempelajari Bahasa Indonesia masih kurang. Adapun faktor eksternalnya ialah pertama: kurangnya kreativitas guru wali kelasnya dalam proses pembelajaran berlangsung, sehingga membuat siswa jenuh dan kurang menyenangkan dalam mengikuti proses pembelajaran Bahasa Indonesia, kemudian metode yang digunakan guru juga tidak bervariasi dan kurang menarik bagi siswa. Kedua: kurangnya perhatian dan dorongan orang tua terhadap prestasi belajar seorang anak, terutama pada proses belajar membaca.

\section{DAFTAR PUSTAKA}

Anggito, Albi, dan Johan Setiawan. Metodologi Penelitian Kualitatif. Jawa Barat: Jejak, 2018.

Anzar, Safni Febri, dan dkk. "Analisis Kesulitan Belajar Siswa Pada Pembelajaran Bahasa Indonesia Di Kelas V Sd Negeri 20 Meulaboh Kabupaten Aceh Barat Tahun Ajaran 2015/2016, Meulaboh.” Bina Gogik 4, no. 1 (2017).

Djamarah. Proses Belajar Mengajar. Jakarta: Bumi Aksara, 2006.

Fadhillah. Wawancara. Jakarta Timur: UNJ PRESS, 2021.

Magdalena, Ina, dan dkk. "Analisis Kesulitan Belajar Siswa Pada Pembelajaran Bahasa Indonesia Di Kelas 5 Sdn Dukuh 3." Jurnal Pendidikan dan Dakwah 3, no. 2 (2021).

Makmun. Psikologi Pendidikan. Bandung: Remaja Rosdakarya, 2001.

Mardhatillah. "Pengembangan Media Pembelajaran Interaktif Berbasis TIK pada Materi Teks Narasi di SDN 106161 Laut Dendang.” Jurnal Tematik 1, no. 16 (2015).

_. "Pengembangan Media Pembelajaran Interaktif Berbasis TIK pada Materi Teks Narasi di SDN 106161 Laut Dendang." Jurnal Bina Gogik 2, no. 2 (2016).

Nani, dan dkk. "Analisis Kesulitan Belajar Siswa Pada Pembelajaran Bahasa Indonesia Di Kelas V SDN 12 Singkawang." Journal of Educational Review and Research 2, no. 1 (2019).

Nugrahani, Farida. Metode Penelitian Kualitatif. Surakarta, 2014.

Simanjuntal, L. Metodologi Mengajar. Jakarta: Rineka Cipta, 2004.

Slameto. Belajar dan Faktor-faktor Yang Mempengaruhinya. Jakarta: PT. Rineka Cipta, 2005.

Sugiyono. Metodologi Penelitian Kuantitatif, Kualitatif, dan R\&D. Bandung: Alfabeta, 2013.

Suraji, Imam. “Urgensi Kompetensi Guru.” Forum Tarbiyah 10, no. 2 (t.t.). 
Winiari, I Gst. Ayu, dan dkk. "Analisis Kesulitan-Kesulitan Belajar Bahasa Indonesia Kelas V Dalam Implementasi Kurikulum 2013 Di Sd Pilotingse-Kabupaten Gianyar.” Jurnal PGSD Universitas Ganesha Jurusan PGSD 3, no. 1 (2015).

Yeni, Ety Meuklesi. "Kesulitan Belajar Matematika Disekolah Dasar." Jurnal JUPENDAS 2, no. 2 (2015). 